\title{
Assessing forest fire behavior simulation using FlamMap software and remote sensing techniques in Western Black Sea Region, Turkey
}

\author{
Mehmet YAVUZ*1, Bülent SAĞLAM ${ }^{1}$, Ömer KÜÇÜK², Aydın TÜFEKÇİĞLU ${ }^{1}$ \\ ${ }^{1}$ Artvin Çoruh University, Faculty of Forestry, Department of Forest Engineering, Artvin, TURKEY \\ ${ }^{2}$ Kastamonu University, Faculty of Forestry, Department of Forest Engineering, Kastamonu, \\ TURKEY \\ *Corresponding author: myavuz@artvin.edu.tr
}

Received Date: 19.02.2018

Accepted Date: 18.06 .2018

\section{Abstract}

Aim of study: Forest fuels are very critical for fire behavior models and hazard maps. Relationship among wind speed, fuel moisture content, slope, and fuel type directs us to predict fire behavior of a given region. For this study, we evaluated fire behavior parameters such as fireline intensity and rate of fire spread using the fuel moisture content, slope, fuel load, and wind speed for the Bayam Forest District with the help of remote sensing techniques and FlamMap software.

Area of study: The study area is located in Bayam Forest District in the city of Taskopru, Kastamonu, a Western Black Sea region of Turkey.

Material and Methods: In order to estimate and map forest fuel load of the study area, fuel models were developed using the parameters of the average vegetation height, 1-hr, 10-hr, and 100-hr fuel load, foliage, total fuel load, litter load and litter depth. Three basic fire descriptors (fireline intensity, rate of fire spread, and flame length) were calculated using FlamMap software with the parameters fuel load, wind speed, fuel moisture, and slope. Using the descriptors above, the historical fire data was overlaid with the fireline intensity maps to determine fire potential areas within the remote sensing and GIS framework.

Main results: The results of this study showed that $20.0 \%$ of the region had low $\left(<2 \mathrm{~m} \mathrm{~min}^{-1}\right), 43.2 \%$ had moderate $(2-$ $\left.15 \mathrm{~m} \mathrm{~min}^{-1}\right), 12.0 \%$ had high $\left(15-30 \mathrm{~m} \mathrm{~min}^{-1}\right)$, and $24.8 \%$ had very high $\left(>30 \mathrm{~m} \mathrm{~min}^{-1}\right)$ rate of fire spread, respectively. The fireline intensity map showed that $60.7 \%$ of the area was in low $\left(0-350 \mathrm{~kW} \mathrm{~m}^{-1}\right), 24.9 \%$ was in moderate $\left(350-1700 \mathrm{~kW} \mathrm{~m}^{-}\right.$ $\left.{ }^{1}\right), 1.3 \%$ was in high $\left(1700-3500 \mathrm{~kW} \mathrm{~m}^{-1}\right)$, and $13.0 \%$ was in very high $\left(>3500 \mathrm{~kW} \mathrm{~m}^{-1}\right)$ fireline intensity.

Highlights: The spatial extent of fuel types was observed and three of the potential fire behavior predictors (fire intensity, rate of fire spread and flame length) were estimated using remote sensing and GIS techniques. The overlaid historical fire data showed that the most fire-prone areas are in the mixed young Anatolian black pine - Scots pine tree stands that have $40-70 \%$ canopy cover and that are in the young Anatolian black pine tree stands that have more than $70 \%$ canopy cover.

Keywords: Fire simulation, fire risk mapping, rate of fire spread, fireline intensity, Bayam Forest District

\section{Batı Karadeniz Bölgesinde FlamMap yazılımı ve uzaktan algılama teknikleri kullanılarak orman yangın davranışı simülasyonunun değerlendirilmesi}

Özet

Çalı̧̧manın amacı: Yanıcı madde tipleri ve tüketilebilir yanıcı madde miktarı yangın davranışının modellenmesinde, yangın şiddetinin hesaplanmasında ve yangın tehlike riskinin haritalanmasında çok önemlidir. Yanıcı madde tipi, yanıcı madde nem içeriği, rüzgâr hızı ve eğim arasındaki ilişki, belirli bir bölgenin yangın davranışının tahmin edilmesinde kullanılan önemli parametrelerden bazılarıdır. Bu çalışmada, Bayam Orman İşletme Şefliğine ait ormanlarda yanıcı madde özellikleri, hava halleri ve bazı topoğrafik özellikler kullanılarak yangın şiddeti ve yangın yayılma oranı haritaları ile yangın risk haritaları uzaktan algılama teknikleri ve FlamMap yazılımı yardımıyla geliştirilmiştir.

Çalışma alanı: Çalışma alanı Türkiye'nin batı Karadeniz bölgesinde bulunan Kastamonu ili, Taşköprü ilçesi, Bayam Orman İşletme Şefliği sınırlarını kapsamaktadır.

Materyal ve Yöntem: Çalışma alanının yanıcı madde miktarını tahmin etmek ve haritalamak için yanıcı madde modelleri kullanılmıștır. FlamMap yazılımı kullanılarak yanıcı madde miktarı, yanıcı madde nem içeriğĭ, rüzgâr hızı ve eğim parametrelerine bağlı olarak yayılma oranı ve yangın şiddeti tahmin edilmiştir. Geçmişte çıkan yangın verileri ile baş yangın şiddeti haritaları çakıştırlarak potansiyel yangın tehlikesi olan yerler CBS ve uzaktan algılama teknikleri kullanarak belirlenmiştir.

Sonuçlar: Bölgenin \%20,0'sının düşük $\left(<2 \mathrm{~m}^{2}\right.$ dakika $\left.^{-1}\right), \% 43,2$ 'inin orta $\left(2-15 \mathrm{~m}\right.$ dakika $\left.{ }^{-1}\right), \% 12,0^{\prime}$ ü yüksek $\left(15-30 \mathrm{~m} \mathrm{dakika}^{-1}\right)$ ve $\% 24,8$ 'si sırasıyla, çok yüksek (> 30 m.dakika $^{-1}$ ) yayılma oranına sahiptir. Yangın şiddeti haritasına göre, alanın \%60,7'unun düşük $\left(0-350 \mathrm{~kW} \mathrm{~m}^{-1}\right), \% 24,9$ 'nin orta $\left(350-1700 \mathrm{~kW} \mathrm{~m}^{-1}\right), \% 1,3$ 'ü yüksek (1700-3500 $\left.\mathrm{kW} \mathrm{m}^{-1}\right)$ ve \%13,0'si çok yüksek $(>3500$ $\mathrm{kW} \mathrm{m}^{-1}$ ) yangın şiddeti sınıfında yer almaktadır.

Önemli Vurgular: Bu çalışmayla çalışma alanına ait yanıcı madde türlerinin mekansal dağılımı haritalanmıș ve yangın davranıșı parametrelerinden üçü (baş yangın şiddeti, yayılma oranı ve alev yüksekliği) uzaktan algılama ve CBS teknikleri kullanılarak tahmin edilmiştir. Daha önce yanan alanların yangın davranış modeli çıktı verileriyle uzamsal olarak çakıştırılması sonucunda, en çok yangına maruz kalan alanların \% 40-70 kapalılığındaki karışık genç Anadolu karaçamı ile sarıçam meşcereleri ile kapalılığı \%70'den fazla olan genç Anadolu karaçam meşcerelerinin bulunduğu alanlarda olduğu sonucuna varılmıştır.

Anahtar Kelimeler: Yangın simülasyonu, yangın şiddeti, yayılma oranı, yangın risk haritası, Bayam Orman İşletme Şefliği

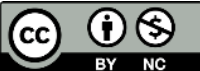




\section{Introduction}

Wildfires are a big threat to not only the natural resources but also to the ecological services such as protecting critical wildlife habitat, keeping the drinking water clean, carbon storage, woody and non-woody products, preserving the recreational lands (Alexander, 1982; Rothermel, 1983; Ager et al., 2011). Public expectation to suppress wildfires and reduce fire occurrences while protecting the ecosystem puts heavy pressure on public and private land managers and planners due to its difficulty and the raised cost of wide range fuel treatment activities such as thinning, pruning the fuel ladders, creating fuel breaks, and grinding of the live and dead surface tree materials (Agee et al., 2000; Agee and Skinner, 2005). Standardization in fuel characterization across diverse lands with regard to fuel-type maps is needed to be used in the fire behavior modeling for a wide spectrum of natural forest fuels characteristics (e.g. fuel load, bulk density, size) found within a specific area. The needs have resulted in the development of fuel models (Burgan, 1987; Lutes et al., 2009). Fuel models are products whose simulated fuel element complexes have chemical and physical parameter values that represent an average fuel condition of a particular vegetation model (Deeming et al., 1972; Rothermel, 1972; Alexander, 1982; Rothermel, 1983; Mallinis et al., 2008).

Fuel models support local fire behavior prediction, but also fire danger rating systems when potential fuel hazard or fire behavior assessment is necessary in landscape fire management planning (Anderson, 1982). Differences in fire behavior, under similar meteorological and topographic conditions, are determined by fuel characteristics (Anderson, 1982; Chandler et al., 1983; Pyne et al., 1996; Nelson, 2001; Bilgili and Saglam, 2003; Bilgili et al., 2006; Kucuk et al., 2012). A fuel model describes fuel complex elements through their average properties values (Burgan and Rothermel, 1984). Therefore, a fuel model is based on the physical rather than the floristic characteristics of a fuel complex. A single fuel model can be applied to numerous vegetation types whose fuel definitions are similar to those represented by the model (Dimitrakopoulos, 2002; Kucuk et al., 2015). The National Forest Fire Laboratory (NFFL) in the US has 13 fuel types developed for BEHAVE system (Andrews, 2007), while Canadian Forest Fire Behavior Prediction System uses 16 discrete fuel types (Lawson et al., 1985). The American and Canadian systems are inspired by the researchers around Europe and they have developed seven fuel models based on the same NFFL fuel types (Arroyo et al., 2008).

The use of remotely sensed data in forest fuel mapping studies is very popular and useful among many researchers (Keane et al., 2001; Saglam et al., 2008; Krasnow et al., 2009; Yavuz and Saglam, 2012; Sivrikaya et al., 2014) to respond quickly to fire suppression scenarios. Topographic layers and fuel layers needed to simulate crown and surface fire grown and intensity can be derived from stand characteristics and remotely sensed data in a fine scale (Farris et al., 1999; Arroyo et al., 2008; Sağlam et al., 2008; Krasnow et al., 2009; Ager et al., 2011; Yavuz and Saglam, 2012). The stand characteristics such as crown closure, species composition, and stand height can be obtained directly, the crown base height can be indirectly obtained from the national forest inventory database.

The complex fuel management and risk assessment planning require sophisticated fire behavior model software from stand level to landscape level to simulate the fire behavior and map the areas under risk. Fire growth simulation models can also be used to predict fire behavior and after effects in identifying spatial variability across a burn area for prescribed burning based on differences in topography (aspect, slope), fuels (moisture contents, fuel loads, and fuel types), and microclimate (wind speed, temperature, and humidity) (Pearce, 2009). The use of fire simulators was proposed by several authors as a convenient methodology to derive fire severity and probability maps in function of different fuel reduction treatments and environmental conditions (Farris et al., 1999; Stratton, 2004; Finney, 2005, 2006; Stratton, 2006; Arca et al., 2007; Harrington et al., 2007; Ager and Finney, 2009; Ager et al., 2011; Finney et al., 2013). 
NEXUS (Scott, 1999), FFE-FVS (Rebain et al., 2010), FARSITE (Finney, 1998), BehavePlus (Andrews, 2007), FSIM (Finney et al., 2011), ArcFuels (Ager et al., 2011), Prometheus (Tymstra et al., 2010) and FlamMap (Finney, 2006) are some of the fire behavior and mapping software that are used for the National Fire Danger Rating System (NFDRS) in the United States and the Forest Fire Behavior Prediction System (FBP) in Canada. The models developed in the US, Canada and Australia such as FARSITE, ProMetheus, SIROFire, Phoenix (Coleman and Sullivan, 1996), and FlamMap are also commonly used for fire behavior analysis in Europe (Mitsopoulos et al., 2017). A complete or partial review of over 40 hazardous fire management tools and software are available by various reviewers based on capabilities, advantages, and weaknesses of these software (Andrews et al., 2007; Peterson et al., 2007; Pearce, 2009; Ager et al., 2011; Miller and Ager, 2013). Many models were developed as part of basic fire behavior research, yet a few models is developed for fuel management planning (Peterson et al., 2007; Ager et al., 2011).

FlamMap is one of a widely accepted fire behavior modeling, fuel management and mapping software in landscape level (Finney, 2006). It is able to make fire behavior calculations for each location independently from one another with one set of environmental conditions (Finney, 2006). FlamMap outputs provide useful information on fire management and well suited to landscape comparisons to determining dangerous fuel, topographic and weather combinations to assess fire hazard and prioritize the field crew in operative phases (Stratton, 2004; Stratton, 2006; Ager and Finney, 2009) and can be used by other fire management planning software without converting to another data format (Ager et al., 2011). In order to evaluate landscape planning, assess fire risk, and secure people safety in the forested urban areas and protect high valued assets around wildlands and infrastructures, the FlamMap simulator and Minimum Travel Time (MTT) fire growth algorithm (Finney, 2006; Ager and Finney, 2009) have been used in most of the spatial fire behavior modeling studies in Europe (Mitsopoulos et al., 2014; Alcasena et al., 2015; Salis et al., 2015; Mitsopoulos et al., 2017). Topographic data, forest characteristics, the weather scenario and fuel moisture data are four major categories that FlamMap uses as inputs (Finney, 2006).

Although it is historically regarded as a very humid and wet, the Western Black Sea region stretching along the coast of Black Sea, has recently been experiencing a large number of forest fires and as a result having extensive fire damages (Kucuk et al., 2012; Aricak et al., 2014). The big fires started in the Black Sea region (Borsuk and Zibtsev, 2013; Kucuk et al., 2015) raised the concerns that the forest fires can lift and spread again the radioactive remedies and radiation on the plants left by the Chernobyl Nuclear accident (Charles, 2010; Zibtsev et al., 2015) in the affected regions. The European Community started a program called "INTERREG IV 'Black Sea Basin Joint Operational Programme 2007-2013" to seek a better way to suppress forest fires using new and innovative technologies in Greece, Moldova, Romania, Armenia, Ukraine and Turkey (Zaimes et al., 2013). The conifer forests grown in the Western Black Sea region have large areas of Anatolian black pine stands (Pinus nigra); thus this region has been reassessed a little while back as being a high potential forest fire risk area. Developing fuel models and determining their fire behavior potential are of vital importance in forest, land, and fire management in the Western Black Sea region (Kucuk et al., 2017; Mitsopoulos et al., 2017). Therefore, the aim of this study is to assess three fire behavior descriptors (fireline intensity, rate of fire spread and flame length) using the fuel load, weather and topographic characteristics for the Bayam Forest District in Kastamonu, Turkey with the help of remote sensing techniques and FlamMap software. The forest fuels from ground, surface and canopy and fire hazard categories were also mapped for the study area.

\section{Materials and Methods Description of the Study Area}

The study area is located within the boundaries of the Bayam Forest District in 
Kastamonu, Turkey. The area lies between the $34^{\circ} 13^{\prime} 12^{\prime \prime} \mathrm{E}$ and $34^{\circ} 26^{\prime} 30^{\prime \prime} \mathrm{E}$ longitude and the $41^{\circ} 27^{\prime} 24^{\prime \prime} \mathrm{N}$ and $41^{\circ} 35^{\prime} 11^{\prime \prime} \mathrm{N}$ latitude. The study site covers 16,006 ha of lands that are mostly forested $(80 \%)$. The remaining lands $(20 \%)$ are used for residential, hay production, and agricultural purposes. (Figure1). The terrain is hilly with an average slope of $25 \%$. The lowest altitude is $500 \mathrm{~m}$ and goes up to $1800 \mathrm{~m}$ as the highest point above the mean sea level across the region. The climate is the humid semi continental Black Sea climate and the average temperature is $10{ }^{\circ} \mathrm{C}$ for the study area and ranges between -4 and $27^{\circ} \mathrm{C}$. The average annual rainfall is $449.6 \mathrm{~mm}$ year $^{-1}$ and the active vegetation period starts in April and ends in October (TSMS, 2017). The major coniferous species in the site are Scotts pine (Pinus Sylvestris L.) and black pine (Pinus nigra supsp. pallasiana). The deciduous tree species include common hornbeam (Carpinus betulus L.), oriental beech (Fagus orientalis Lipsky), field elm
(Ulmus minor Gill.) and various oak (Quercus spp.) species (GDF, 2009). The main soil type under the forested lands is brown forest soils (combisol-leptosol and combisol). The most of the black pine and deciduous tree stands grow on the lands with the combisol-leptosol soil type. The agricultural lands have mostly the haptic kastanozems soil type. Stream banks and their riparian zones where the herbaceous and shrub vegetation grow, consist of fluvisol soil types (GDF, 2009; GDAR, 2014).

One of the threats to forested lands in the region's dry and hot summer period is the fire. The total number of fire occurrences is to be 54 with a total of 497 ha forested lands burned between the years 1963-2015 within the study area. Because of that, the Turkish Forest Service placed the study site as the second degree fire sensitivity level based on their fire threat danger system.

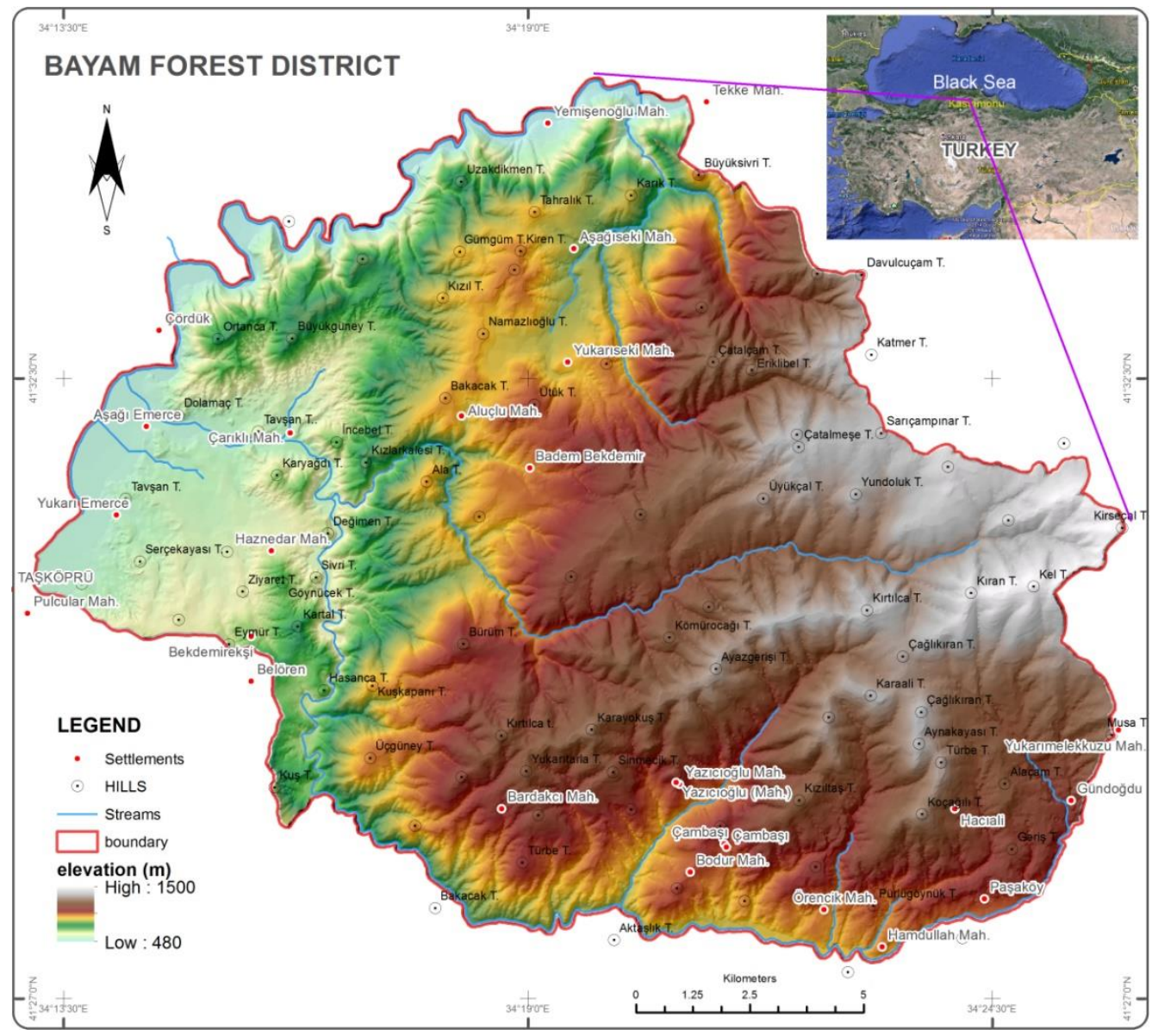

Figure 1. The location of the study area: Bayam Forest District, Kastamonu, TURKEY 


\section{Methods}

Fuel data for each of the four fuel parameters (canopy bulk density, surface fuel model, canopy height, and crown base height) for each of the 40 sampling plots were used to create fuel models. Two moisture models (live and dead) were used to measure percent fuel moisture content for the each fuel type. The live fuel moisture content was further divided into herbaceous and woody shrub. The dead fuel moisture content was measured on the dead fuels at the 1-,10,100-h time-lag basis (Cohen and Deeming, 1985). Later, the models were placed in the ArcGIS system (ESRI, 2014) to form gridfuel maps for the woodland in the Bayam Forest District. The resulting maps and fuel maps for the same area were then used to assess potential fire hazard using the FlamMap software (Finney, 2006). The detailed procedures are described as following.

\section{Forest Fuel Sampling and Data}

In order to determine the forest fuel loads, all the areas in the study sites were stratified on vegetation maps according to the dominant vegetation and/or land use type (e.g.: pasture, developed, shrubs, and forest stands). Subsequently, all the stratified areas were surveyed on site and $40(1 \times 1 \mathrm{~m})$ representative sampling points with similar fuel conditions for each area were randomly selected. In each sampling plots, the following fuel parameters were measured: a) Average vegetation height $(\mathrm{m})$ with $1 / 10$ meter precision, b) 1 -hr fuel load $(\mathrm{kg})$ fuel with diameter class from $0-0.6 \mathrm{~cm}$, c) $10-\mathrm{hr}$ fuel load $(\mathrm{kg})$ fuel with diameter class from $0.6-2.5 \mathrm{~cm}$, d) $100-\mathrm{hr}$ fuel load $(\mathrm{kg})$ fuel with diameter class from $2.5-7.5 \mathrm{~cm}$, e) live foliage $(\varnothing<6 \mathrm{~mm})(\mathrm{kg})$, f) total fuel load $(\mathrm{kg})$, g) litter load $(\mathrm{kg})$ and h) litter depth (cm) (Brown et al., 1982; Sağlam et al., 2008). All fuel sampling studies took place in the fire season (June-September) of 2013.

The average plant height $(\mathrm{H})$ is measured as the vertical distance from the top of the branches to the ground surface. The measurements were taken at three points along a transect passing through the sampling plot and were averaged to calculate the average height value for the plot. A destructive sampling of all the vegetation parts in the fuel components was performed. The 1-hour, 10-hours, 100-hours, and total fuel loads were measured by clip and weight method (Brown et al., 1982). Litter depth, foliage, herbaceous (dead and live) vegetation, shrubs that are up to $2.0 \mathrm{~m}$ in height, and litter loads were measured in each sampling plot. All fuel loads (fuel weight per unit surface area) were expressed on a dry weight basis. The most common fuel parameters found in the forest understory and forest floor are herbaceous vegetation, dead leaves, and needles. The depth of the litter (dead leaves and needles) was also measured with a ruler on each sampling plot. All vegetation stems were cut at the ground, and separated into components of leaves and branches. The sampled plots were cleared, and then all the dead and live woody parts less than $7.5 \mathrm{~cm}$ in diameter were further separated into three diameter size classes $(0-0.6 \mathrm{~cm}, 0.6-2.5 \mathrm{~cm}$ and 2.5 $7.5 \mathrm{~cm}$ ) (Roussopoulos and Loomis, 1979; Martin et al., 1981; Brown, 1982; Brown et al., 1982; Saglam et al., 2008). Because the Rothermal's spread model that was used in FlamMap software does not run with live fuels greater than $\varnothing>6 \mathrm{~mm}$, we did not measure any live woody plant materials larger than $6 \mathrm{~mm}$ in diameter. The size classes given here were corresponded to the $1-, \quad 10-$, and 100-hour time-lag fuels described in the literature (Deeming et al., 1972) and were important fuel biomass categories useful in calculating the intensity and severity of fires. Having completed the classification of fuel categories, all dead and live fuels were weighed in site using a $0.1 \mathrm{~g}$ sensitive electronic scale. Then, subsamples of fuel biomass from each category were taken, weighed again, placed in plastic bags, labeled and transferred to the laboratory for calculating oven-dry weights. All subsamples were oven-dried at $105{ }^{\circ} \mathrm{C}$ for 24 hours and then weighed again with the same scale. The percent fuel moisture content (FMC) was calculated by subtracting dry weight $\left(\mathrm{W}_{\mathrm{d}}\right)$ from fresh weight $\left(\mathrm{W}_{\mathrm{f}}\right)$ and then dividing the result by dry weight using the following equation (Deeming et al., 1972): 


$$
F M C=\frac{\text { fresh weight }- \text { dry weight }}{\text { dry weight }} \times 100
$$

While fuel models were being developed, stand types with similar characteristics in coverage, height, age, quantity and depth of fuel material were assessed in the same fuel model category. Finally, forest fuel load was determined as tons per hectare using all fuel type, size, and percent fuel moisture content.

\section{Fuel Mapping Procedures}

Fuel type mapping was carried out using the satellite imagery that was acquired in 2012 by the AIRBUS Defense and Space operated Astrium Pleiades-1A satellite (CNES, 2017). The images have one $50-\mathrm{cm}$ panchromatic $(0.480-0.830 \mu)$ and four 2meter multispectral bands (Blue: 0.430-0.550 $\mu$, Green: 0.490-0.610 $\mu$, Red: 0.600-0.720 $\mu$, and Near Infrared: $0.750-0.950 \mu$ ). The multispectral bands were color-balanced, pan-sharpened to get $50 \mathrm{~cm}$ spatial resolution and orthorectified by using 10-m DEM provided by the National Mapping Agency of Turkey. The original, 3-m within the $90 \%$ Circular Error (CE90), location accuracy of images was improved by $1-\mathrm{m}$ using ground control points (GCP) from the cadastral maps that were renewed in 2009. The final product imagery that is covering $168 \mathrm{~km}^{2}$, then was classified into 20 initial land cover classes by using ISODATA unsupervised algorithm that embedded within ERDAS Imagine software package (ERDAS, 2008). Then each class was assigned a Land Use/Land Cover (LULC) class using Anderson (1976) classification scheme based on the visual assessment and field data observations. Normalized Difference Vegetation Index (NDVI) was used along with the original satellite imagery in order to separate bare lands and green vegetation and calculated as following (Jensen, 2007).

$$
N D V I=\frac{\mathrm{NIR}-\mathrm{RED}}{\mathrm{NIR}+\mathrm{RED}}
$$

Where NIR is the near infrared and RED is the red band of the satellite imagery.

The classification information from the satellite imagery was not sufficiently detailed enough to show forest floor and understory vegetation information to produce fuel maps that can be used for fire hazard and fire suppression mapping. To resolve this problem, we used the satellite imagery information and information from Turkish Forest Service inventory (GDF, 2009) data and maps that were produced from the color infrared stereo-paired aerial photos taken in 2009 for the study area. The vegetation boundaries and species composition information were also derived using a manual, hands-on vegetation delineation approach where boundaries were first hand digitized around individual land cover features and then were assigned with a class label (Jensen, 2007) for ambiguous areas where the mixed classes were hard to distinguish. However, it was considered a labor extensive process (Maxwell, 2010; Blaschke et al., 2014), yet the quality and effectiveness of the results were gratifying.

The field verified stand development stage information and canopy cover information from 68 forest stands were used to acquire major tree species types, canopy closure, and average stand height information for the study area. In each forest stand type, the major and secondary tree species at the top of canopy, stand development stage, DBH and percent crown closure were measured and symbolized as shown in Table 1 and Table 2.

Table 1. Stand development stages and corresponding DBH range used in the Bayam Forest District

\begin{tabular}{lcc}
\hline $\begin{array}{l}\text { Stand Development } \\
\text { Stages }\end{array}$ & Symbol & DBH (cm) \\
\hline Stand initiation & a & $0-7.9$ \\
Sapling-pole & b & $8.0-19.9$ \\
Intermediate & c & $20.0-35.9$ \\
Understory reinitiation & d & $36.0-51.9$ \\
Old growth & e & 52.0 and up \\
\hline
\end{tabular}

Table 2. Canopy coverage classes and their range in percent used in the Bayam Forest District

\begin{tabular}{lcc}
\hline $\begin{array}{l}\text { Canopy Closure } \\
\text { Class }\end{array}$ & Symbol & $\begin{array}{c}\text { Canopy Closure } \\
(\%)\end{array}$ \\
\hline no crown closure & 0 & $0-10$ \\
low & 1 & $11-40$ \\
moderate & 2 & $41-70$ \\
high & 3 & $71-100$ \\
\hline
\end{tabular}


Once the vegetation map that was created using remotely sensed and forest inventory data, the fuel models calculated in the previous section were assigned to each corresponding vegetation LULC class type based on the forest stand type, the major and secondary tree species at the overstory, stand development stage and percent canopy closure data using ESRI's ArcGIS 10.2.1 software (ESRI, 2014).

\section{Fire Behavior Simulation Parameters}

The FlamMap software was chosen as one of a few landscape level fire behavior simulator developed at the USDA Rocky Mountain Research Station (Finney, 2006; Stratton, 2006) for estimating fire behavior parameters such as the fireline intensity $(\mathrm{kW}$ $\left.\mathrm{min}^{-1}\right)$ and rate of fire spread $\left(\mathrm{m} \mathrm{min}^{-1}\right)$ with the Rothermel (1972)'s fire spread and Rothermel (1983)'s fireline intensity equations that are already embedded in the software. In depth discussion of its usage, discussion and calculation related to these two descriptors of fire behavior can be found in Byram (1959), Alexander (1982), Wade (1986), and Cruz and Alexander (2010). The eight gridded spatial inputs including topographic features (slope in degrees, elevation, and aspect) from the DEM of the study area, fuel canopy characteristics (canopy height, canopy cover, canopy base height, and canopy bulk density) and the spatial extent of the surface fuel models and weather data (Maximum Air Temperature, Average Wind Speed and Average Wind Direction) in the study area (Table 4) were included to simulate the landscape fire behavior into the FlamMap based on the Huygen's wavelet propagation principle (Finney, 2006). The $5 \times 5 \mathrm{~m}$ grid size was used for the DEM derived data files and fuel model input raster files within the FlamMap simulator. The historical weather data and fire occurrence data observed in the study area was used to obtain dominant wind direction and wind speed values (95 percentile) in each burning condition during the summer months. The wind blowing was set to upslope direction.

The fuel moisture content layer was created using the values created from the 1-, $10-$, and 100-h time lagged oven dried fuels.
Dead fuels' moisture content values were estimated by using the Fine Fuel Moisture Code (FFMC) of the Canadian Forest Fire Weather Index (FWI) System's dead fuel moisture prediction equations (Aguado et al., 2007). For the live herbaceous fuel moisture content values, Dimitrakopoulos and Bemmerzouk (2003)'s equation was used for each fuel type found in the study area (Table 4). Canopy cover information for the forested areas was obtained from both national forest inventory database and Astrium Pleiades-1A satellite imagery taken in 2012. The field verified forest canopy cover information from 68 pure and mixed forest stands types was classified into four canopy cover categories as depicted in Table 2.

The heat content values which is a comprehensive measure of thermal energy release for a given fuel (Susott et al., 1975) were taken from Dimitrakopoulos and Panov (2001) and Kucuk et al. (2015) studies.

Surface area-to-volume ratio for fuel particles in each fuel model as well as dead fuel moisture of extinction was taken values calculated by Dimitrakopoulos and Panov (2001) and Fernandes et al. (2009). The spotting and crowning modules were not activated while running the FlamMap software. The fire behavior outputs resulted from the FlamMap runs are the ASCII files of fireline intensity and rate of fire spread values and were used to estimate fire behavior and fire hazard risks for the study area.

Table 3. A range of fireline intensity, rate of fire spread and flame length values categorized by Andrews et al. (2011)

\begin{tabular}{lccc}
\hline Categories & $\begin{array}{c}\text { Fireline } \\
\text { Intensity } \\
\left(\mathrm{kW} \mathrm{m}^{-1}\right)\end{array}$ & $\begin{array}{c}\text { Rate of fire } \\
\text { spread } \\
\left(\mathrm{m} \mathrm{min}^{-1}\right)\end{array}$ & $\begin{array}{c}\text { Flame } \\
\text { Length } \\
(\mathrm{m})\end{array}$ \\
\hline Low & $0-350$ & $0-2$ & $0-1.2$ \\
Moderate & $350-1700$ & $2-15$ & $1.2-2.4$ \\
High & $1700-3500$ & $15-30$ & $2.4-3.4$ \\
Very High & $>3500$ & $>30$ & $>3.4$ \\
\hline
\end{tabular}

We used four distinct categories (low, moderate, high, and very high) which are based on the Andrews et al. (2011)'s fireline intensity classes and Andrews and Rothermel (1982)'s rate of fire spread classes to 
evaluate the fire behavior outputs and to make fireline intensity, rate of fire spread and flame length maps for the study area (Table 3). We preferred Andrews et al. (2011)'s four category classification over the six fireline intensity classes that are conceptually introduced in Hirsch (1996) and are formally adopted in Field Guide to the Canadian Forest Fire Behaviour Prediction (FBP) System (Taylor and Alexander, 2017) in order to make comparison between fire behavior outputs.

Table 4. Weather and fuel moisture parameters that are derived from fuel sampling and fuel mapping procedures are used as inputs for the FlamMap software

\begin{tabular}{|c|c|c|c|c|c|c|c|c|}
\hline \multirow[t]{2}{*}{ Parameters } & \multicolumn{8}{|c|}{ Fuel Moisture Content (\%) } \\
\hline & FM14 & FM15 & FM16 & FM17 & FM18 & FM19 & FM20 & FM21 \\
\hline 1 -h fuel $(0-0.64 \mathrm{~cm})(\%)$ & 8 & 12 & 17 & 16 & 17 & 6 & 12 & 12 \\
\hline 10 -h fuel $(0.65-2.5 \mathrm{~cm})(\%)$ & 10 & 21 & 21 & 24 & 22 & 21 & 18 & 20 \\
\hline 100 -h fuel $(2.51-7.5 \mathrm{~cm})(\%)$ & 12 & 24 & 24 & 26 & 24 & 25 & 25 & 26 \\
\hline Live herbaceous fuel (\%) & 100 & 100 & 100 & 100 & 100 & 100 & 100 & 100 \\
\hline Live woody fuel $(\varnothing<6 \mathrm{~mm})(\%)$ & 120 & 106 & 110 & 116 & 120 & 120 & 104 & 120 \\
\hline Surface to Volume Ratio (1HSAV- $-\mathrm{cm}^{-1}$ ) & 74 & 74 & 74 & 74 & 74 & 74 & 74 & 74 \\
\hline Surface to Volume Ratio (LiveHSAV- $\mathrm{cm}^{-1}$ ) & 54 & 54 & 51 & 51 & 49 & 51 & 51 & 51 \\
\hline Surface to Volume Ratio (LiveWSAV- $\mathrm{cm}^{-1}$ ) & 44 & 44 & 41 & 41 & 39 & 41 & 41 & 41 \\
\hline Fuel Bed (Litter) Depth (cm) & 1.00 & 2.50 & 1.00 & 2.80 & 3.20 & 1.00 & 2.13 & 1.50 \\
\hline Moisture of Extinction (XtMoist) (\%) & 15 & 25 & 30 & 35 & 35 & 35 & 25 & 35 \\
\hline Heat Content Live Fuel (LHt) $\left(\mathrm{J} \mathrm{Kg}^{-1}\right)$ & 20500 & 20500 & 20500 & 20500 & 20500 & 20500 & 20500 & 20500 \\
\hline Heat Content Dead Fuel (DHt) $\left(\mathrm{J} \mathrm{Kg}^{-1}\right)$ & 18595 & 18595 & 18595 & 18595 & 18595 & 18595 & 18595 & 18595 \\
\hline Wind speed $\left(\mathrm{km} \mathrm{h}^{-1}\right)$ & 20 & 20 & 20 & 20 & 20 & 20 & 20 & 20 \\
\hline Wind direction & $\mathrm{NE}$ & $\mathrm{NE}$ & $\mathrm{NE}$ & $\mathrm{NE}$ & $\mathrm{NE}$ & $\mathrm{NE}$ & $\mathrm{NE}$ & $\mathrm{NE}$ \\
\hline
\end{tabular}

\section{Results and Discussion}

Fuel Models and Types

The seven fuel models that we resulted from the field sampling have represented all the major vegetation types of the study area (Table 5). The first fuel model (FM15), "Litter Layer of Young Anatolian Black Pine", having a crown closure greater than $70 \%$ was incorporated with mostly planted 3 $\mathrm{m}$ tall Anatolian black pine trees. This model was responsible for an average proportion of the foliage load in the study area. The second fuel model (FM16) was the "Litter Layer of Young Anatolian Black Pine and Scots Pine" (crown closure 40-70\%) that was responsible for $0.13 \%$ of total fuel load. The third fuel model (FM17) was the "Litter Layer of Young Anatolian Black Pine" (crown closure $>70 \%$ ). It covers $13 \%$ of the study area and was responsible for $29 \%$ of the total fuel load. The fourth fuel model (FM18) was the "Litter Layer of Mature Anatolian Black Pine with Understory" (crown closure 40-70\%). It covers $24 \%$ of the study area while representing $17 \%$ of the total fuel load $(4.93 \mathrm{t}$ $\mathrm{ha}^{-1}$ ). The fifth fuel model (FM19), "Litter Layer of Mature Anatolian Black Pine" (crown closure $>70 \%$ ), had a $17 \%$ of the study area and was attributed $22.8 \%$ of the total fuel load. The seventh fuel model (FM20) was "Litter Layer of Mature Scots Pine with Understory (Crown Closure 4070)". The eighth fuel model (FM21), "Open Area Oak Fuel Type", covering 24\% of the total study area represented $6.5 \%\left(1.83 \mathrm{t} \mathrm{ha}^{-1}\right)$ of the total fuel load. The remaining portion of the area (19.65\%) was assigned to the fuel model zero (FM14) which was covered by developed (settlement), agricultural and pasture lands.

Since the properties of the fuel types have a fundamental place in fire behavior simulations, any kind of numerical data of the fuel models affect the reliability of the simulation outputs (Kucuk et al., 2015). All the surface fuel loads by size classes and fuel 
types are depicted in Table 6 and were used in the fire behavior simulator as inputs.

Table 5. Fuel models that are created based on the field measurements

\begin{tabular}{cll}
\hline Model Number & & Model Description \\
\hline FM14 & $:$ & Areas of developed, agricultural and pasture lands \\
FM15 & $:$ & Litter Layer of Young Anatolian Black Pine (Crown Closure $>70)$ \\
FM16 & $:$ & Litter Layer of Young Anatolian Black Pine and Scots Pine (Crown Closure 40-70) \\
FM17 & $:$ & Litter Layer of Young Anatolian Black Pine (Crown Closure $>70)$ \\
FM18 & $:$ & Litter Layer of Mature Anatolian Black Pine with Understory (Crown Closure 40-70) \\
FM19 & $:$ & Litter Layer of Mature Anatolian Black Pine (Crown Closure $>70)$ \\
FM20 & $:$ & Litter Layer of Mature Scots Pine with Understory (Crown Closure 40-70) \\
FM21 & $:$ & Open Area Oak Fuel Type \\
\hline
\end{tabular}

Table 6. Surface fuel loads that were measured during the field sampling procedure for each fuel model in the study site

\begin{tabular}{|c|c|c|c|c|c|c|}
\hline \multirow[b]{3}{*}{ Time lag -> } & \multicolumn{3}{|c|}{ Surface fuel load by size classes } & \multirow{3}{*}{$\begin{array}{c}\text { Live } \\
\text { foliage } \\
(\varnothing<6 \mathrm{~mm})\end{array}$} & \multirow{3}{*}{ Litter load } & \multirow{3}{*}{$\begin{array}{l}\text { Litter } \\
\text { Depth }\end{array}$} \\
\hline & $0.0-0.6 \mathrm{~cm}$ & $0.6-2.5 \mathrm{~cm}$ & $2.6-7.5 \mathrm{~cm}$ & & & \\
\hline & $1-\mathrm{h}$ & 10-h & 100-h & & & \\
\hline Fuel Model & $t h^{-1}$ & $\mathrm{tha}^{-1}$ & $t h^{-1}$ & $t^{h^{-1}}$ & $t^{h^{-1}}$ & $\mathrm{~cm}$ \\
\hline FM14 & 0.100 & - & - & 0.050 & 0.050 & 1.00 \\
\hline FM15 & 0.840 & 0.280 & 0.980 & - & 1.870 & 2.50 \\
\hline FM16 & 0.440 & - & - & 1.960 & 0.460 & 1.00 \\
\hline FM17 & 1.080 & 0.960 & 3.490 & - & 2.670 & 2.80 \\
\hline FM18 & 0.250 & 0.630 & 1.200 & 0.420 & 2.430 & 2.00 \\
\hline FM19 & 1.110 & 1.460 & 0.730 & - & 3.120 & 3.20 \\
\hline FM20 & 1.892 & 2.834 & 9.502 & 2.375 & 1.304 & 2.25 \\
\hline FM21 & 0.080 & 0.080 & - & 1.280 & 0.390 & 1.50 \\
\hline
\end{tabular}

\section{Fuel spatial extent and fire simulation results}

A thirty percent of the study area was dominated by Anatolian black pine $(4123.5$ ha). As the second dominant species, $13 \%$ of the forested area (1061 ha) was occupied by the Scots pine. The remaining forested lands were covered by oak (1908 ha), oriental beech ( $98.5 \mathrm{ha}$ ) and Calabrian pine (33.5 ha).

More than half $(60.7 \%)$ of the study area showed a fireline intensity of less than 350 $\mathrm{kW} \mathrm{m} \mathrm{m}^{-1}$ due to the low fuel load in pasture lands, agricultural areas, and forest openings. The quarter $(24.9 \%)$ of the study site has a capacity to produce moderately intense fires $\left(350-1700 \mathrm{~kW} \mathrm{~m}^{-1}\right)$. The high $\left(1700-3500 \mathrm{~kW} \mathrm{~m}^{-1}\right)$ and very high fireline intensities $\left(>3500 \mathrm{~kW} \mathrm{~m}^{-1}\right)$ were resulted from the all seven fuel models that each covered 1.3 and $13.0 \%$ of the area, respectively (Table 7).

We estimated that $20.0 \%$ of the region has low $\left(2 \mathrm{~m} \mathrm{~min}^{-1}\right), 43.2 \%$ of that has moderate $\left(2-15 \mathrm{~m} \mathrm{~min}^{-1}\right), 12.0 \%$ of that has high (15$30 \mathrm{~m} \mathrm{~min}^{-1}$ ), and $24.8 \%$ of that has very high $\left(>30 \mathrm{~m} \mathrm{~min}^{-1}\right)$ rate of fire spread, respectively (Table 7).

Looking at the fire spread rate, $62.2 \%$ of the area shows low and medium spread rates combined. Although the mean values are used, especially when the weather data is assumed to be constant during the simulation, the changes in the wind, especially in the short time period, are not reflected in the simulation. Changes in the direction and severity of the wind caused the 
fire behavior outcomes to vary. As a matter

et al. (2015) and Sullivan (2009). of fact, similar situation is indicated by Kelso

Table 7. Area coverage by Fireline Intensity, Rate of Fire Spread, and Flame Length Categories for the Bayam Forest District in Kastamonu, Turkey

\begin{tabular}{|c|c|c|c|c|c|}
\hline $\begin{array}{l}\text { Fireline Intensity } \\
\left(\mathrm{kW} \mathrm{m}^{-1}\right)\end{array}$ & $\begin{array}{c}\text { Portion of } \\
\text { Area } \\
(\%)\end{array}$ & $\begin{array}{l}\text { Rate of Fire Spread } \\
\left(\mathrm{m} \mathrm{min}^{-1}\right)\end{array}$ & $\begin{array}{c}\text { Portion of } \\
\text { Area } \\
(\%)\end{array}$ & $\begin{array}{l}\text { Flame Length } \\
\text { (m) }\end{array}$ & $\begin{array}{c}\text { Portion of } \\
\text { Area } \\
(\%)\end{array}$ \\
\hline Low $(0-350)$ & 60.7 & Low $(<2)$ & 20.0 & Low $(0-1.2)$ & 22.8 \\
\hline Moderate $(350-1700)$ & 24.9 & Moderate (2-15) & 43.2 & Moderate (1.2-2.4) & 12.2 \\
\hline High (1700-3500) & 1.3 & High (15-30) & 12.0 & High (2.4-3.4) & 21.7 \\
\hline Very High $(>3500)$ & 13.0 & Very High $(>30)$ & 24.8 & Very High $(>3.4)$ & 43.4 \\
\hline
\end{tabular}

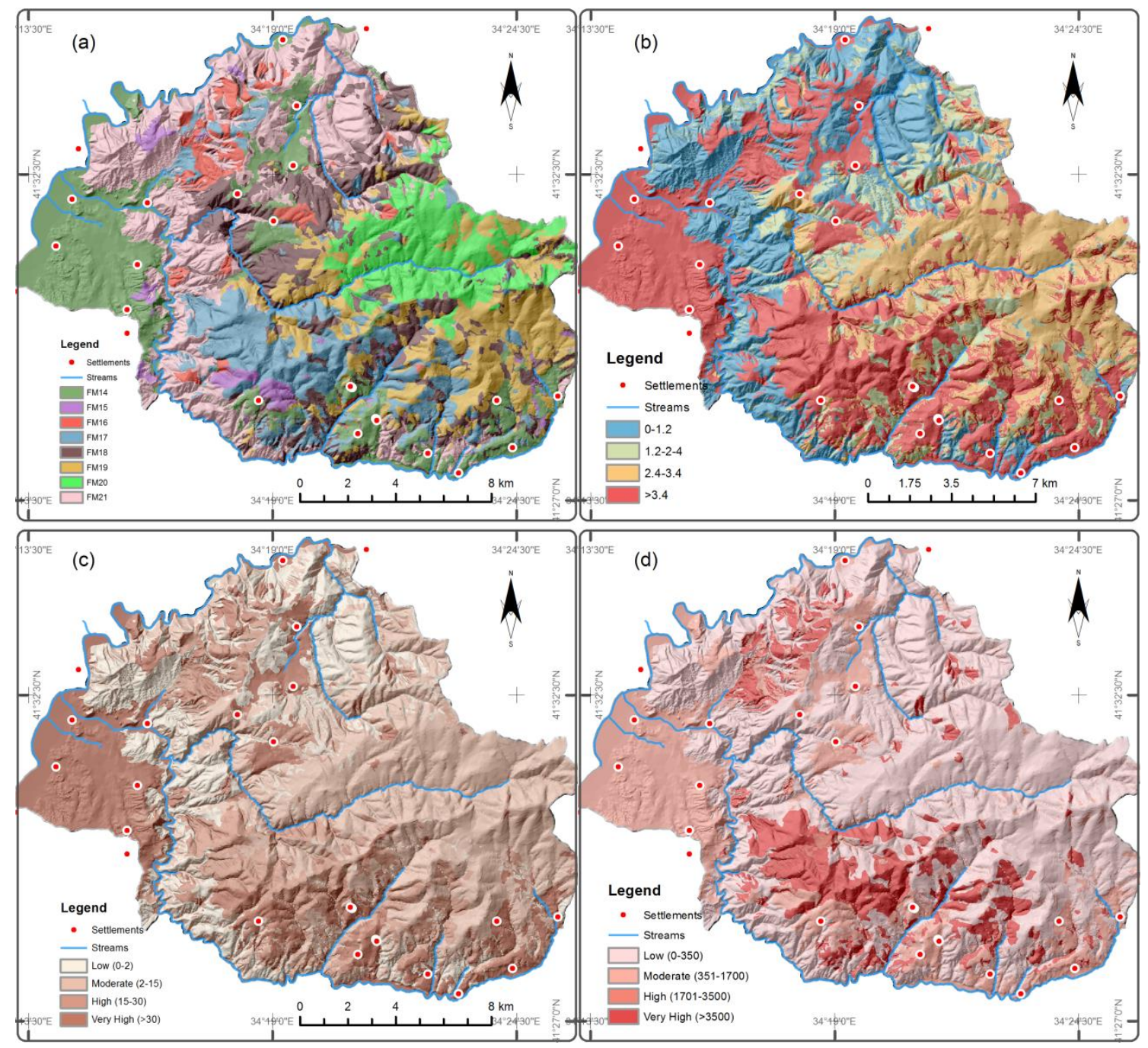

Figure 2. FlamMap outputs for the Bayam Forest District: a) Fuel Type Map, b) Flame Length Map, c) Rate of Fire Spread Map, and d) Fireline Intensity Map

The flame lengths were estimated that $22.8 \%$ of the study area can produce $0-1.2 \mathrm{~m}$ flames and 12.2 of that can resulted 1.2-2.4 $\mathrm{m}$ flames. The high category flame lengths (2.3-3.4 m) can be resulted $21.7 \%$ of the area. The very high flame length category which can produce greater than $3 \mathrm{~m}$ flames, was estimated covering $43.4 \%$ of the study area (Table 7). 
The fuel types that produce low fireline intensity $\left(<350 \mathrm{~kW} \mathrm{~m}^{-1}\right)$ in the study area are FM18, FM 19, FM20 and FM21. The flame length in these areas ranges from 0.9 to 3.3 $\mathrm{m}$. The canopy height in these areas is about $15-20 \mathrm{~m}$. These areas have low potential to be reached a crown fire with a very slow rate of fire spread (1.6-9.6 $\left.\mathrm{m} \mathrm{min}^{-1}\right)$.

The agricultural and grass lands showed moderately intense fires $\left(532 \mathrm{~kW} \mathrm{~m}^{-1}\right)$ with a faster fire spread rate $\left(100.2 \mathrm{~m} \mathrm{~min}^{-1}\right)$. This is an expected result for the crop stalk residues within the agricultural areas in the summer time after crop harvesting. However the flame length that reaching $4.6 \mathrm{~m}$ can be attributed to the tall shrubs grown within these areas.

The simulation results showed that the area has plenty of potential fuels to produce 22.2 and $29.9 \mathrm{~m}$ flame length for FM16 and FM17 fuel types, respectively (Table 8). Furthermore these areas are categorized as a very high fireline intensity class. The FM16 fuel type that is estimated to produce moderately intense fires in the study area and showed an average flame length of $6.1 \mathrm{~m}$.

Areas with high fireline intensities were found in locations that are mostly south-west facing aspect with an average slope of 30 percent. The heaviest fuel concentration was found in the areas burned previously and replanted right after. These areas create conditions that are favorable for rapid rate of fire spread and intense fire growth. This was due to lacks of thinning practices on the very dense young tree stands existed in the replanted areas. We evaluated and observed in the field that areas burned many times recently by the wildfires have a low fuel load and are under low fire risk potential.

Table 8. Mean Fireline Intensity, Mean Rate of fire spread and Mean Flame Length for each Fuel Model Type in the study area

\begin{tabular}{lrrr}
\hline $\begin{array}{l}\text { Fuel Model } \\
\text { Type }\end{array}$ & $\begin{array}{r}\text { Mean Fireline } \\
\text { Intensity }\end{array}$ & $\begin{array}{r}\text { Mean Rate } \\
\text { of fire } \\
\text { spread } \\
\mathrm{m} \mathrm{min}^{-1}\end{array}$ & $\begin{array}{r}\text { Mean } \\
\text { Flame } \\
\text { Length }\end{array}$ \\
\hline FM14 & 532.0 & 100.2 & 4.6 \\
FM15 & 1022.6 & 35.7 & 6.1 \\
FM16 & 5370.7 & 40.1 & 22.2 \\
FM17 & 6530.8 & 22.1 & 29.9 \\
FM18 & 72.7 & 5.0 & 1.7 \\
FM19 & 267.3 & 9.6 & 3.3 \\
FM20 & 234.4 & 7.2 & 3.1 \\
FM21 & 17.6 & 1.6 & 0.9 \\
\hline
\end{tabular}

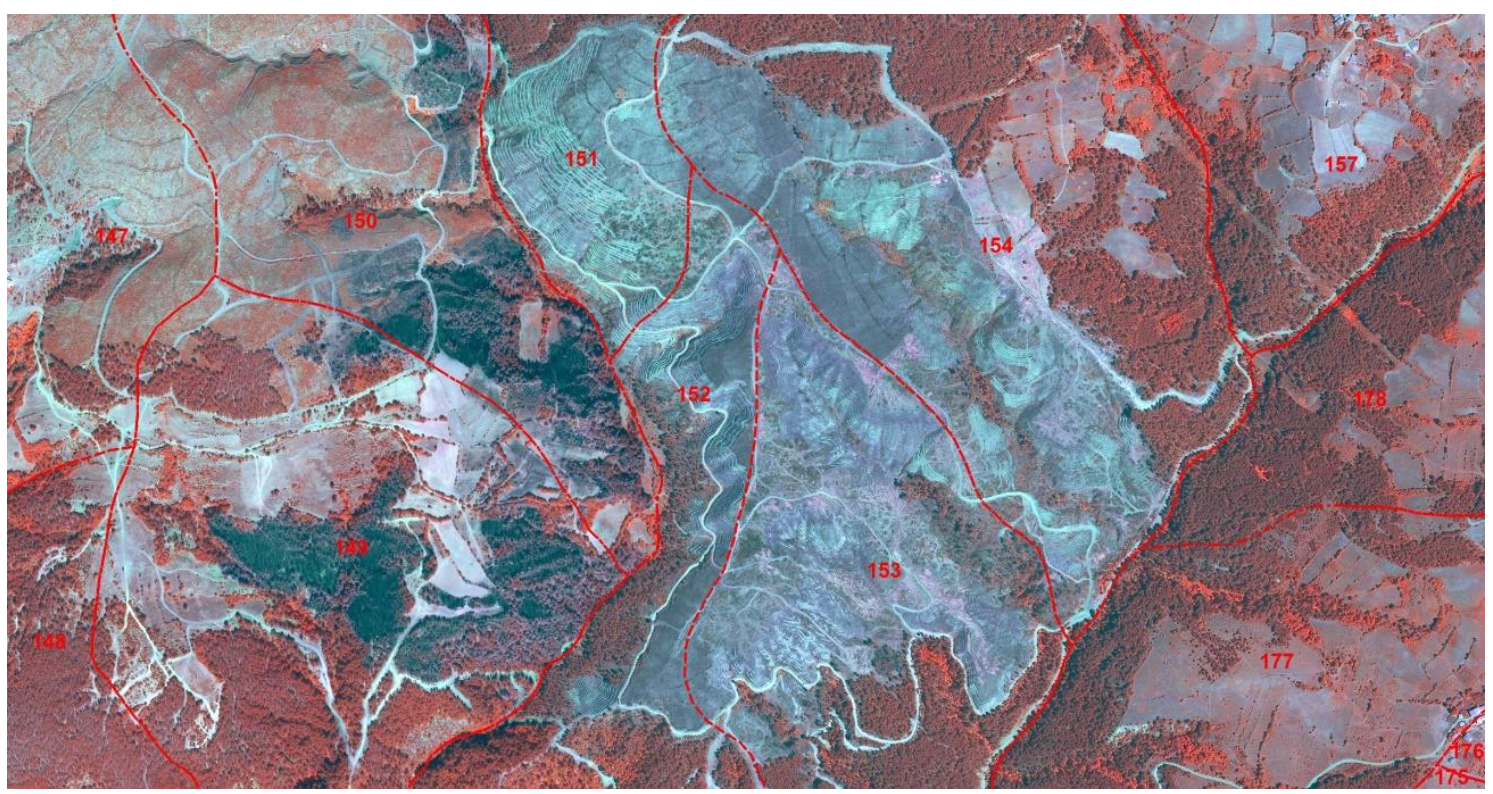

Figure 3. Overlay of compartment boundaries (dashed red lines) and recently burned areas in $2003(147,150)$, in $2012(151,152,153,154)$ and in $2013(149,150)$ within the study site 
The historical fire data overlay with the fireline intensity map showed that the previously burned areas are mostly located where degraded oak stands and degraded Anatolian black pine tree stands join (Figure 3 and Figure 4). The degraded Anatolian black pine tree stands have a very low site index and the stand height is about 3-4 m tall in the southern part of the study area. We believed that the fine fuel remnants left by the local villagers when preparing firewood for their needs increased the fuel accumulation under the young pine stands.

Aricak et al. (2014) reported similar results that $12.09 \%$ of their degraded Anatolian black pine stands is under very high fire risk potential. They found ten fuel types comparing to eight fuel types in our study site. This can be attributed to the different tree species compositions in the forest stands where Scots pine and Anatolian black pine had mixed stands. However, having fire behavior models and fire fuel maps for the Anatolian black pine and the Scots pine mixed stands provided an advantage to our study compared to the other studies.

The fire suppression difficulty maps that had been created by Yavuz et al. (2015) and Mitsopoulos et al. (2017) for the similar fuel type characteristics in Turkey, Greece and Ukraine showed similar results to our findings for the fireline intensity and rate of fire spread classes.

The most important constraints and limitations in many studies on fire modeling are the inability to provide the required correct data, and variability of these variables for different areas. In this study, it was seen that different results were obtained when reflecting every situation in the meteorological data, especially in the simulations. The similar results were achieved in the studies by Arca et al. (2007) and Ager et al. (2011).

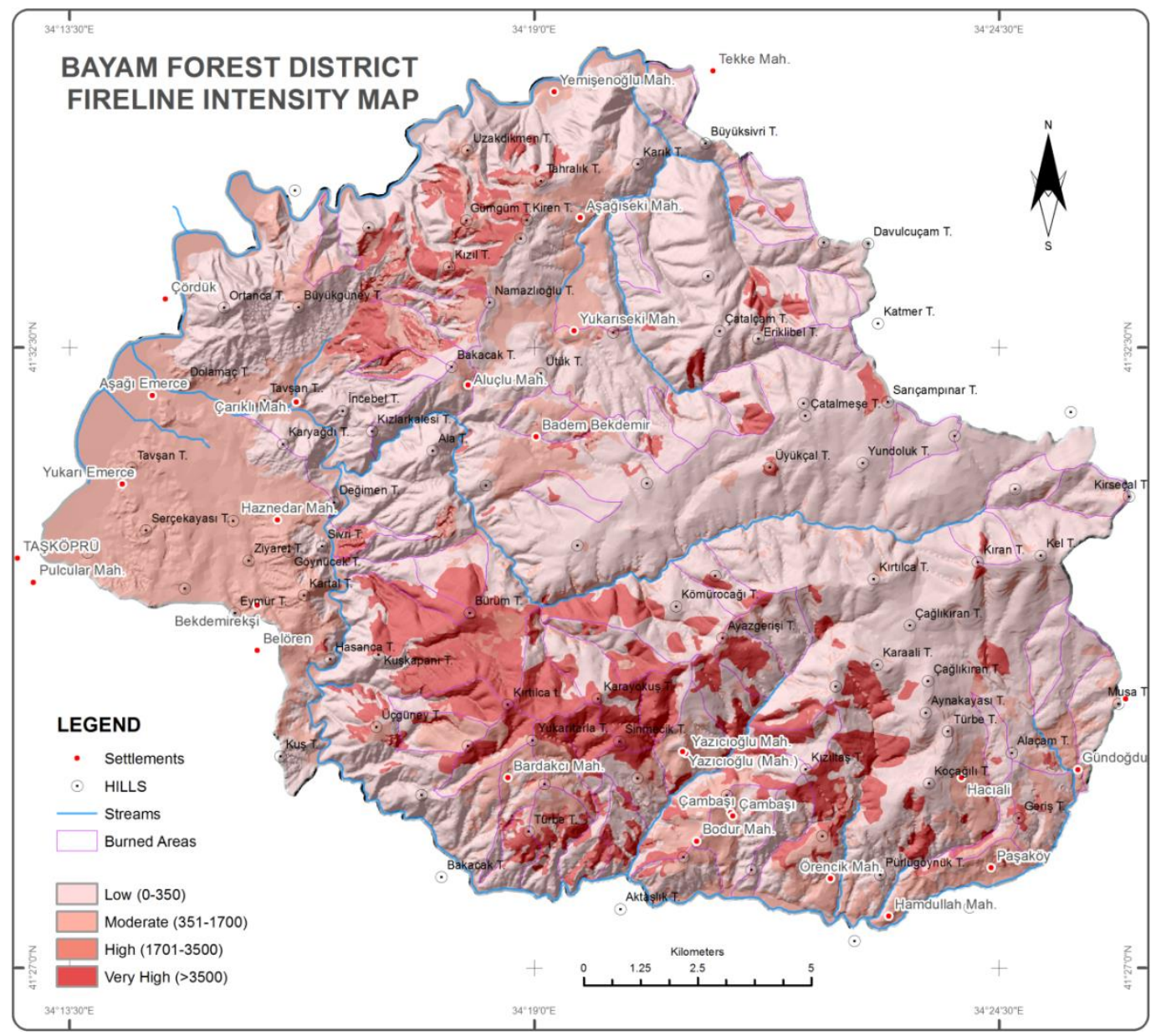

Figure 4. The fireline intensity map with historical fire data overlay from 1962 to 2013 
The fuel characteristics are dynamic and change season to season across years due to grazing and human activities within forested lands in the study area. Fuel maps depicted the current status of the forested stands and applying the same forest fuel models to another outside area however is uncertain. New fires can alter the current status of the fire potential areas and decrease the fuel available for combustion. The fire history in the area showed us that the lands under high and very high fire hazard have potential to be burned down again in the near future if the weather conditions are met. In terms of management implications, GIS and remote sensing techniques greatly improved the assessment of the fire behavior models. Many model predictors such as canopy cover, stand height, and base canopy height were derived from the national forest inventory database and can also be derived from very high resolution digital aerial nearIR photographs.

\section{Conclusions}

The spatial extent of fuel type was observed and three of the potential fire behavior predictors (fire intensity, rate of fire spread and flame length) were estimated. The fire hazard categories of the study area are created and analyzed. The results showed that the most fire-prone areas are in the mixed young Anatolian black pine - Scots pine tree stands that have $40-70 \%$ canopy cover and that are in the young Anatolian black pine tree stands that have more than $70 \%$ canopy cover. A special attention must be paid when making decision on the forest management operations such as thinning and practices to decrease available combustible fuels on these areas to reduce the rate of fire spread and fireline intensity dramatically.

\section{Acknowledgements}

This study is an enhanced version of the conference proceedings by Yavuz, M., Saglam, B., Kucuk, O., Tufekcioglu, A. (2015) "Assessing Fuel Load and Fireline Intensity in Bayam Forest District, Turkey Using Flam Map Software and Remote Sensing Techniques" that was presented at International Forest Fire Conference in Black Sea Region held on 6-8 November 2014 in
Kastamonu, TURKEY. The authors would like to thank to the European Community's INTERREG IV 'Black Sea Basin Joint Operational Programme 2007-2013': 'Utilizing Stream Waters in the Suppression of Forest Fires with the Help of New Technologies' (Streams-2-SUPPRESS-Fires) (Grant \#: MIS ETC 2666 nr. 15610/25.02.2013) and the Central Finance and Contracts Unit (CFCU) in TURKEY (Grant\#: TR08C1.01-02/323) that financially supported this work. The authors would like to thanks Dr. Ioannis Mitsopolous from the Global Fire Monitoring Center (GFMC) Freiburg, Germany and anonymous reviewers who helped to greatly improve our manuscript.

\section{References}

Agee, J. K., Bahro, B., Finney, M. A., Omi, P. N., Sapsis, D. B., Skinner, C. N., Van Wagtendonk, J. W., Weatherspoon, C. P. (2000). The use of shaded fuelbreaks in landscape fire management. Forest Ecology and Management, 127(1-3), 5566.

Agee, J. K., Skinner, C. N. (2005). Basic principles of forest fuel reduction treatments. Forest Ecology and Management, 211(1-2), 83-96.

Ager, A. A., Finney, M. A. (2009). Application of wildfire simulation models for risk analysis. Paper presented at the EGU General Assembly Conference Abstracts.

Ager, A. A., Vaillant, N. M., Finney, M. A. (2011). Integrating fire behavior models and geospatial analysis for wildland fire risk assessment and fuel management planning. Journal of Combustion, 2011, 19. doi:10.1155/2011/572452

Aguado, I., Chuvieco, E., Boren, R., Nieto, H. (2007). Estimation of dead fuel moisture content from meteorological data in Mediterranean areas. Applications in fire danger assessment. International Journal of Wildland Fire, 16(4), 390-397.

Alcasena, F. J., Salis, M., Ager, A. A., Arca, B., Molina, D., Spano, D. (2015). Assessing landscape scale wildfire exposure for highly valued resources in a Mediterranean area. Environmental management, 55(5), 1200-1216. 
Alexander, M. E. (1982). Calculating and Interpreting Forest Fire Intensities. Canadian Journal of Botany-Revue Canadienne De Botanique, 60(4), 349357. doi:DOI 10.1139/b82-048

Anderson, H. E. (1982). Aids to determining fuel models for estimating fire behavior. USDA For. Serv. Gen. Tech. Rep. INT122. Intermt. For. and Range Exp. Stn., Ogden, Utah 84401., 22.

Anderson, J. R. (1976). A land use and land cover classification system for use with remote sensor data (Vol. 964): US Government Printing Office. USGS Professional Paper 964. A revision of the land use classification system as presented in the USGS Circular 671.

Andrews, P., Finney, M., Fischetti, M. (2007). Predicting wildfires. Scientific American, 297(2), 46-55.

Andrews, P. L. (2007). BehavePlus fire modeling system: past, present, and future. Paper presented at the Proceedings of 7 th symposium on fire and forest meteorology.

Andrews, P. L., Heinsch, F. A., Schelvan, L. (2011). How to generate and interpret fire characteristics charts for surface and crown fire behavior: United States Department of Agriculture, Forest Service, Rocky Mountain Research Station.

Andrews, P. L., Rothermel, R. C. (1982). Charts for interpreting wildland fire behavior characteristics. Gen. Tech. Rep. INT-131. Ogden, UT: US Department of Agriculture, Forest Service, Intermountain Forest and Range Experiment Station. 21 p, 131.

Arca, B., Duce, P., Laconi, M., Pellizzaro, G., Salis, M., Spano, D. (2007). Evaluation of FARSITE simulator in Mediterranean maquis. International Journal of Wildland Fire, 16(5), 563-572.

Aricak, B., Kucuk, O., Enez, K. (2014). Determining a fire potential map based on stand age, stand closure and tree species, using satellite imagery (Kastamonu central forest directorate sample). Croatian Journal of Forest Engineering: Journal for Theory and Application of Forestry Engineering, 35(1), 101-108.
Arroyo, L. A., Pascual, C., Manzanera, J. A. (2008). Fire models and methods to map fuel types: the role of remote sensing. Forest Ecology and Management, 256(6), 1239-1252.

Bilgili, E., Durmaz, B. D., Saglam, B., Kucuk, O., Baysal, I. (2006). Fire behaviour in immature calabrian pine plantations. Forest Ecology and Management, $\quad 234, \quad$ S112. doi:https://doi.org/10.1016/j.foreco.2006. $\underline{08.148}$

Bilgili, E., Saglam, B. (2003). Fire behavior in maquis fuels in Turkey. Forest Ecology and Management, 184(1), 201-207. doi:https://doi.org/10.1016/S03781127(03)00208-1

Blaschke, T., Hay, G. J., Kelly, M., Lang, S., Hofmann, P., Addink, E., Queiroz Feitosa, R., van der Meer, F., van der Werff, H., van Coillie, F., Tiede, D. (2014). Geographic Object-Based Image Analysis - Towards a new paradigm. ISPRS Journal of Photogrammetry and Remote Sensing, 87(Supplement C), 180191.

doi:https://doi.org/10.1016/j.isprsjprs.201 3.09.014

Borsuk, A., Zibtsev, S. (2013). Fire History in Mountain Forests of the Crimean Peninsula of Ukraine. Paper presented at the International Caucasia Forestry Symposium.

Brown, J. K. (1982). Fuel and fire behavior prediction in big sagebrush: US Department of Agriculture, Forest Service, Intermountain Forest and Range Experiment Station.

Brown, J. K., Oberheu, R. D., Johnston, C. M. (1982). Handbook for inventorying surface fuels and biomass in the Interior West. USDA Forest Service, Intermountain Forest and Range Experiment Station General Technical Report INT-129. Ogden.

Burgan, R. E. (1987). Concepts and interpreted examples in advanced fuel modeling. Gen. Tech. Rep. INT-238. Ogden, UT: US Department of Agriculture, Forest Service, Intermountain Research Station. 40 p., 238,40 . 
Burgan, R. E., Rothermel, R. C. (1984). BEHAVE: fire behavior prediction and fuel modeling system--FUEL subsystem. The Bark Beetles, Fuels, and Fire Bibliography, 47.

Byram, G. (1959). Forest fire behavior. In K. Davis (Ed.), Forest fire: Control and use (pp. 90-123). New York, NY: McGrawHill.

Chandler, C., Cheney, P., Thomas, P., Trabaud, L., Williams, D. (1983). Fire in forestry. Volume 1. Forest fire behavior and effects. Volume 2. Forest fire management and organization: John Wiley \& Sons, Inc.

Charles, D. (2010). Russia's Forest Fires Ignite Concerns About Chornobyl's Legacy. Science, 329(5993), 738-739. doi:10.1126/science.329.5993.738-b

CNES. (2017). National Centre for Space Studies (French Government Space Agency). Retrieved from http://smsc.cnes.fr/PLEIADES/

Cohen, J. D., Deeming, J. E. (1985). The national fire-danger rating system: basic equations. Gen. Tech. Rep. PSW-82. Berkeley, CA: Pacific Southwest Forest and Range Experiment Station, Forest Service, US Department of Agriculture; $16 \mathrm{p}, 82$.

Coleman, J. R., Sullivan, A. L. (1996). A real-time computer application for the prediction of fire spread across the Australian landscape. Simulation, 67(4), 230-240.

Cruz, M. G., Alexander, M. E. (2010). Assessing crown fire potential in coniferous forests of western North America: a critique of current approaches and recent simulation studies. International Journal of Wildland Fire, 19(4), 377-398.

Deeming, I. E., Lancaster, I. W., Fosberg, M. A., Furman, R. W., Schroeder, M. (1972). The National Fire-Danger Rating System USDA Forest Service Research Paper $R M-84$.

Dimitrakopoulos, A. P. (2002). Mediterranean fuel models and potential fire behaviour in Greece. International Journal of Wildland Fire, 11(2), 127-130.

Dimitrakopoulos, A. P., Bemmerzouk, A. M. (2003). Predicting live herbaceous moisture content from a seasonal drought index. International Journal of Biometeorology, 47(2), 73-79.

Dimitrakopoulos, A. P., Panov, P. I. (2001). Pyric properties of some dominant Mediterranean vegetation species. International Journal of Wildland Fire, 10(1), 23-27.

ERDAS. (2008). ERDAS field guide. Georgia. USA: ERDAS Inc. .

ESRI. (2014). ArcGIS for Desktop: Release 10.2.1 (Version 10.2.1). Redlands,CA: Environmental Systems Research Institute.

Farris, C. A., Pezeshki, C., Neuenschwander, L. F. (1999). A comparison of fire probability maps derived from GIS modeling and direct simulation techniques. Paper presented at the Proceedings of the Joint Fire Science Conference and Workshop: Crossing the Millenium: Integrating Spatial Technologies and Ecological Principles for a New Age in Fire Management.

Fernandes, P. M., Botelho, H. S., Rego, F. C., Loureiro, C. (2009). Empirical modelling of surface fire behaviour in maritime pine stands. International Journal of Wildland Fire, 18(6), 698-710. doi:https://doi.org/10.1071/WF08023

Finney, M. A. (1998). FARSITE, Fire Area Simulator-model development and evaluation (Vol. 3): US Department of Agriculture, Forest Service, Rocky Mountain Research Station Ogden, UT.

Finney, M. A. (2005). The challenge of quantitative risk analysis for wildland fire. Forest Ecology and Management, 211(1), 97-108.

doi:https://doi.org/10.1016/j.foreco.2005. 02.010

Finney, M. A. (2006). An overview of FlamMap fire modeling capabilities. Paper presented at the Fuels management-how to measure success: conference proceedings, 28-30 March 2006; Portland, OR.

Finney, M. A., Cohen, J. D., McAllister, S. S., Jolly, W. M. (2013). On the need for a theory of wildland fire spread. International Journal of Wildland Fire, 22(1), 25-36. doi:https://doi.org/10.1071/WF11117 
Finney, M. A., Grenfell, I. C., McHugh, C. W., Seli, R. C., Trethewey, D., Stratton, R. D., Brittain, S. (2011). A method for ensemble wildland fire simulation. Environmental Modeling \& Assessment, 16(2), 153-167.

GDAR. (2014). Great Soil Groups (In Turkish: Türkiye Büyük Toprak Grubu Veri Tabanı Bilgileri).

GDF. (2009). Functional Forest management Plan of Bayam Forest Enterprise. Ankara, Turkey: Republic of Turkey Ministry of Forestry, General Directorate of Forestry.

Harrington, M. G., Noonan-Wright, E., Doherty, M. (2007). Testing the modeled effectiveness of an operational fuel reduction treatment in a small western Montana interface landscape using two spatial scales. Paper presented at the The fire environment-Innovations, management, and policy; conference proceedings, 26-30 March 2008, Destin, FL.

Jensen, J. R. (2007). Remote sensing of the environment: An earth resource perspective (2nd ed.). Upper Saddle River, NJ: Prentice-Hall, Inc.

Keane, R. E., Burgan, R. E., Van Wagtendonk, J. W. (2001). Mapping wildland fuels for fire management across multiple scales: integrating remote sensing, GIS, and biophysical modeling. International Journal of Wildland Fire, 10(4), 301-319. doi:10.1071/WF01028

Kelso, J. K., Mellor, D., Murphy, M. E., Milne, G. J. (2015). Techniques for evaluating wildfire simulators via the simulation of historical fires using the Australis simulator. International Journal of Wildland Fire, 24(6), 784-797.

Krasnow, K., Schoennagel, T., Veblen, T. T. (2009). Forest fuel mapping and evaluation of LANDFIRE fuel maps in Boulder County, Colorado, USA. Forest Ecology and Management, 257(7), 16031612. doi:10.1016/j.foreco.2009.01.020

Kucuk, O., Bilgili, E., Bulut, S., Fernandes, P. M. (2012). Rates of surface fire spread in a young calabrian pine (Pinus brutia Ten.) plantation. Environmental Engineering \& Management Journal (EEMJ), 11(8), 1475-1480.
Kucuk, O., Bilgili, E., Fernandes, P. M. (2015). Fuel modelling and potential fire behavior in Turkey. Šumarski list, 139(11-12), 553-560.

Kucuk, O., Topaloglu, O., Altunel, A. O., Cetin, M. (2017). Visibility analysis of fire lookout towers in the Boyabat State Forest Enterprise in Turkey. Environmental monitoring and assessment, 189(7), 329.

Lawson, B. D., Stocks, B. J., Alexander, M. E., Van Wagner, C. E. (1985). A system for predicting fire behavior in Canadian forests.

Lutes, D. C., Keane, R. E., Caratti, J. F. (2009). A surface fuel classification for estimating fire effects. International Journal of Wildland Fire, 18(7), 802-814.

Mallinis, G., Mitsopoulos, I. D., Dimitrakopoulos, A. P., Gitas, I. Z., Karteris, M. (2008). Local-scale fuel-type mapping and fire behavior prediction by employing high-resolution satellite imagery. IEEE Journal of Selected Topics in Applied Earth Observations and Remote Sensing, 1(4), 230-239.

Martin, R. E., Frewing, D. W., McClanhan, J. L. (1981). Average biomass of four northwest shrubs by fuel size class and crown cover. Portland (OR): USDA Forest Service. Pacific Northwest Forest and Range Experiment Station. Research Note PNW-374.

Maxwell, S. K. (2010). Generating land cover boundaries from remotely sensed data using object-based image analysis: overview and epidemiological application. Spatial and spatio-temporal epidemiology, 1(4), 231-237.

Miller, C., Ager, A. A. (2013). A review of recent advances in risk analysis for wildfire management. International Journal of Wildland Fire, 22(1), 1-14.

Mitsopoulos, I., Mallinis, G., Karali, A., Giannakopoulos, C., Arianoutsou, M. (2014). Mapping fire behaviour in a Mediterranean landscape under different future climate change scenarios. Paper presented at the International Conference ADAPTtoCLIMATE, Nicosia, Cyprus.

Mitsopoulos, I., Mallinis, G., Zibtsev, S., Yavuz, M., Saglam, B., Kucuk, O., Bogomolov, V., Borsuk, A., Zaimes, G. 
(2017). An integrated approach for mapping fire suppression difficulty in three different ecosystems of Eastern Europe. Journal of Spatial Science, 62(1), 139-155.

Nelson, R. M. (2001). Water relations of forest fuels Forest fires (pp. 79-149): Elsevier.

Pearce, H. G. (2009). Review of fire growth simulation models for application in New Zealand. Scion Fire Research Group, Christchurch, NZ. Client Report(16246).

Peterson, D. L., Evers, L., Gravenmier, R. A., Eberhardt, E. (2007). Analytical and decision support for managing vegetation and fuels: A consumer guide. Gen. Tech. Rep. PNW-GTR-690. Portland, OR: USDA Forest Service, Pacific Northwest Research Station.

Pyne, S. J., Andrews, P. L., Laven, R. D. (1996). Introduction to wildland fire (2nd ed.). New York: Wiley.

Rebain, S. A., Reinhardt, E. D., Crookston, N. L., Beukema, S. J., Kurz, W. A., Greenough, J. A., Robinson, D. C. E., Lutes, D. C. (2010). The fire and fuels extension to the forest vegetation simulator: updated model documentation. USDA For. Serv. Int. Rep, 408.

Rothermel, R. C. (1972). A mathematical model for predicting fire spread in wildland fuels. USDA For. Serv. Res. Pap. INT-115.

Rothermel, R. C. (1983). How to predict the spread and intensity of forest and range fires. USDA For. Serv. Gen. Tech. Rep. INT-143.

Roussopoulos, P. J., Loomis, R. M. (1979). Weights and dimensional properties of shrubs and small trees of the Great Lakes conifer forest.

Saglam, B., Bilgili, E., Dincdurmaz, B., Kadiogulari, A. I., Küçük, Ö. (2008). Spatio-temporal analysis of forest fire risk and danger using LANDSAT imagery. Sensors, 8(6), 3970-3987.

Sağlam, B., Küçük, Ö., Bilgili, E., Durmaz, B. D., Baysal, I. (2008). Estimating fuel biomass of some shrub species (Maquis) in Turkey. Turkish Journal of Agriculture and Forestry, 32(4), 349-356.

Salis, M., Ager, A. A., Alcasena, F. J., Arca, B., Finney, M. A., Pellizzaro, G., Spano,
D. (2015). Analyzing seasonal patterns of wildfire exposure factors in Sardinia, Italy. Environmental monitoring and assessment, 187(1), 4175.

Scott, J. H. (1999). NEXUS: a system for assessing crown fire hazard. Fire Management Notes.

Sivrikaya, F., Sağlam, B., Akay, A. E., Bozali, N. (2014). Evaluation of forest fire risk with GIS. Polish Journal of Environmental Studies, 23(1), 187-194.

Stratton, R. D. (2004). Assessing the effectiveness of landscape fuel treatments on fire growth and behavior. Journal of Forestry, 102(7), 32-40.

Stratton, R. D. (2006). Guidance on spatial wildland fire analysis: models, tools, and techniques: United States Department of Agriculture, Forest Service, Rocky Mountain Research Station; General Technical Report RMRS-GTR-183.

Sullivan, A. L. (2009). Wildland surface fire spread modelling, 1990-2007. 3: Simulation and mathematical analogue models. International Journal of Wildland Fire, 18(4), 387-403.

Susott, R. A., DeGroot, W. F., Shafizadeh, F. (1975). Heat content of natural fuels. Journal of Fire and Flammability, 6, 311325.

Taylor, S. W., Alexander, M. E. (2017). Field guide to the Canadian Forest Fire Behavior Prediction (FBP) System (Second Edition ed. Vol. 11). Canada: UBC Press.

TSMS. (2017). Kastamonu Weather Station Data.

Tymstra, C., Bryce, R. W., Wotton, B. M., Taylor, S. W., Armitage, O. B. (2010). Development and structure of Prometheus: the Canadian wildland fire growth simulation model. Natural Resources Canada, Canadian Forest Service, Northern Forestry Centre, Information Report NOR-X417.(Edmonton, $A B$ ).

Wade, D. D. (1986). Linking fire behavior to its effects on living plant tissue. Paper presented at the Proceedings of the : Forests, The World, and The Profession, Society of American Foresters National Convention (USA), October 5-8, 1986; Birmingham, AL 
Yavuz, M., Saglam, B. (2012). Use of remote sensing and geographic information systems techniquies in forest fires. $K S U$ Journal of Engineering Science (Special Issue), 235-242.

Yavuz, M., Saglam, B., Kucuk, O., Tufekcioglu, A. (2015). Assessing fuel load and fireline intensity in Bayam forest district, Turkey using Flam Map software and remote sensing techniquies. Paper presented at the International forest fire conference in Black Sea Region.

Zaimes, G. N., Tufekcioglu, M., Tufekcioglu, A., Zibtsev, S., Kaziolas, D., Yavuz, M., Trombitsky, I., Emmanouloudis, D., Uratu, R., Ghulijanyan, A. (2013). Innovative and sustainable use of stream water to suppress fires in protected areas: overview of the streams-2-suppress-fires project. Paper presented at the International Caucasia Forestry Symposium, Artvin, Turkey.

Zibtsev, S. V., Goldammer, J. G., Robinson, S., Borsuk, O. A. (2015). Fires in nuclear forests: silent threats to the environment and human security. Unasylva, 66(243/244), 40 . 